Catalogue of the Fossil Cephalopoda in the British Museum (Natural History)

Part 4: The Ammonoidea of the Trias. By Dr. L. F. Spath. Pp. xvi $+521+18$ plates. (London: British Museum (Natural History), 1934.) n.p.

PARTS 1 to 3 of this Catalogue by Foord and Crick, dealing with the Nautiloids and Palæozoic Ammonoids, were published in 1887, 1891 and 1897 respectively. The new part, although of larger size, includes only about half of the Triassic Ammonoids, namely, the Pronoritida, Xenodiscida, Meekoceratida, and part of the Ceratitida, nearly all occurring in the Lower and Middle Trias. The remaining groups, of Middle and Upper Triassic age, will be dealt with in the succeeding volume. Since the last part was published, our knowledge of Palæozoic Ammonoids has increased considerably, so that the author can now affirm that true Ammonites were already prolific in the Upper Palæozoic, and that the Permian System, contrary to the views of some British geologists, has fully justified its existence.

In the introduction the author gives a critical review of the classifications of Goniatites proposed by previous writers, and expresses in tabular form his own view of the interrelations of the Palæozoic Ammonoids and their connexion with the Lower Triassic Ammonites. In a section on "Chronology and Stratigraphy" he gives a very valuable account of the zonal divisions and correlation of the Triassic deposits, and concludes from his study of the successive faunas that the Triassic period was considerably longer than the whole of the Jurassic. The author maintains that faunas found in different regions which, although showing some differences, have been regarded as contemporary, are really heterochronous. At the same time he admits the existence of life-provinces in the Trias, but gives no eriteria by which the differences dependent on age can be distinguished from those due to geographical distribution.

The main part of the Catalogue is devoted to a systematic account of the groups mentioned above, with a discussion of the mutual relationships of the various families and genera. Unlike most writers on the phylogeny of Ammonoids, the author does not accept the evidence of ontogeny, but bases his views on the morphological characters and the stratigraphical succession of forms. His conclusions will be more easily followed if shown in tabular form in the sueceeding volume.

\section{An Introduction to Inorganic Chemistry :}

for B.Sc. Students of the Indian Universities. By Dr. Satya Prakash. Pp. vii +478 . (Allahabad : Kala Press, 1934.) 6 rupees; $10 s$.

Dr. Prakash's book has some unusual features. It deals with the elements in the order of the Periodic System, the inert gases coming first, followed by the metals, and the non-metals come last. This has advantages for a student who has completed an elementary course, since his knowledge of the nonmetals is refreshed again after he has dealt with the new material. A special feature of the book is the stress laid on Indian conditions and interests, a good deal of statistical data being incorporated and the native processes and names being given. This part will be quite valuable to readers wishing to know something of chemical technology in India. Extensive use is made of tables summarising information given in the text.

The text itself is rather condensed, so that a good deal of ground is covered, and the more elementary parts of the subject are briefly treated. Whilst full equations are given in the text, the summary tables contain unbalanced equations with arrows, such as $\mathrm{NaHSC}_{3}+\mathrm{Zn}+\mathrm{SO}_{2} \rightarrow \mathrm{Na}_{2} \mathrm{~S}_{2} \mathrm{O}_{4}$, which are liable to lead to neglect of the correct equations by weaker students. Dr. Prakash's book is an interesting one of good standard. The English is not always very good, and should be revised in future editions.

\section{Dynamo-Electric Machine in its Historical Develop-} ment :

Documents and Materials. Collected by D. V. Efremov and M. I. Radovskij. Edited by V. Th. Mitkevitch. (Academy of Sciences of the U.S.S.R. : Transactions of the Institute for the History of Science and Technology, Series 3, Issue 1.) Pp. xviii +560 . (Leningrad : Academy of Sciences Press, 1934.) 15 roubles.

THIs volume gives the leading papers and extracts from books, etc., from which we can see the gradual historical development of the modern dynamo. The frontispiece gives a portrait of Faraday and the book begins with his discovery of electromagnetic induction. Practically all the book is in Russian, so it will make a limited appeal to English readers. The table of contents proves that a very wide research has been made through the literature of European countries. It is the first issue of Series III in the Transactions of the Russian Institute for the History of Science and Technology. The printing is very clear, but some of the diagrams have not come out very well.

\section{Hand- und Jahrbuch der chemischen Physik}

Herausgegeben von A. Eucken und K. L. Wolf. Band 6, Abschnitt 1A : Elektronenstrahlen und ihre Wechselwirkung mit Materie. Von J. Hengstenberg und Karl Wolf. Pp. 236+12. (Leipzig: Akademische Verlagsgesellschaft m.b.H., 1935.) 24 gold marks.

THE discovery of electron beams is traced back to Pflücker (1859) and the recognition of their nature to Schuster's first determination of the ratio of charge to mass in 1884 ; but their principal interest arises from the discovery of interference effects, depending on a wave-like character of the electron. This has been demonstrated by the development of Debye-Scherrer rings by scattering (i) in thin films of a solid as in G. P. Thomson's already classical experiments with gold foil and the more recent beautiful photographs of G. I. Finch, and (ii) in vapours, as studied by Mark and Wierl in Ludwigshafen and later in England by de Laszlo. These and cognate topics are reviewed in a monograph which covers 236 pages and includes 182 figures. 